\title{
PENGARUH PERILAKU BIROKRASI TERHADAP PELAYANAN PUBLIK DI DESA TIMORENG PANUA KECAMATAN PANCA RIJANG KABUPATEN SIDENRENG RAPPANG
}

\author{
Ulfa Rafika Fajriah, Muhammad Rais Rahmat Razak \\ IImu Pemerintahan, Fakultas IImu Sosial dan IImu Politik, Universitas Muhammadiyah Sidenreng Rappang \\ ulfarafika43151056e1@gmail.com; mraisrahmat@umsrappang.ac.id
}

\begin{abstract}
Abstrak
Penelitian ini bertujuan untuk mengetahui apakah perilaku birokrasi dan pelayanan publik memiliki pengaruh yang signifikan di Desa Timoreng Panua Kabupaten Sidenreng Rappang. Populasi penelitian ini adalah keseluruhan masyarakat yang mendapatkan pelayanan di Desa Timoreng panua kabupaten Sidenreng Rappang, adapun populasi yang diambil mulai dari bulan November 2018 - Januari 2019 yang berjumlah 57 orang. Sampel dalam penelitian ini adalah sampling jenuh. Tipe dan jenis penelitian ini adalah deskriftif kuantitatif. Teknik pengumpulan data yang digunakan dalam penelitian ini adalah Observasi, Dokumentasi, Kuisioner, Studi Pustaka. Data yang terkumpul selanjutnya dianalisis menggunakan analisis tabulasi frekuensi dan SPSS 16,0. Hasil penelitian ini untuk indikator Perilaku Birokrasi menunjukkan 61,9\% dari jumlah data yang dihasilkan berada pada kategori "baik". Dan pada indikator Pelayanan Publik menunjukkan $64,84 \%$ dari jumlah data yang dihasilkan berada pada kategori "baik". Berdasarkan hasil Perilaku birokrasi terhadap pelayanan publik di kantor desa Timoreng Panua Kabupaten Sidenreng Rappang, memiliki pengaruh sebesar $24,0 \%$ dengan kategori "kurang baik".
\end{abstract}

Kata Kunci : Perilaku birokrasi, dan Pelayanan Publik

\begin{abstract}
This study aims to determine whether bureaucratic behavior and public services have a significant influence in the Timoreng Panua Village, Sidenreng Rappang Regency.The population of this study is the whole community who received service in the village of Timoreng Panua, Sidenreng Rappang district, as for the population taken from November 2018 - January 2019, totaling 57 people. The sample in this study is saturated sampling. This type and type of research is quantitative descriptive. Data collection techniques used in this study are Observation, Documentation, Questionnaire, Library Study. The collected data was then analyzed using frequency tabulation analysis and SPSS 16.0. The results of this study for indicators of Bureaucratic Behavior show $61.9 \%$ of the amount of data produced is in the "good" category. And on the Public Service indicator shows $64.84 \%$ of the amount of data produced is in the "good" category. Based on the results of bureaucratic behavior towards public services in the Timoreng Panua village office in Sidenreng Rappang Regency, it has an influence of $24.0 \%$ with the category "less good".
\end{abstract}

Keywords: Bureaucratic Behavior, Public Service

PRAJA| Volume 8| Nomor 1| Edisi Februari 2020 


\section{A. PENDAHULUAN}

Birokrasi dimaknai sebagai suatu bentuk institusi. Pada jaman Mesir Kuno telah melahirkan birokrasi skala besar yang ada di dunia. Yang dimana pengaturan birokrasinya mendasarkan diri pada ajaran-ajaran tentang kepegawaian. Birokrasi merupakan instrumen penting dalam masyarakat modern. Dalam hal ini negara dituntun terlibat dalam memproduksikan barang dan jasa yang diperlukan oleh rakyat baik secara langsung maupun tidak langsung. Birokrasi bagi sebagian orang dimaknai dengan prosedur yang berbelit-belit, dan menyulitkan, namun yang lain, birokrasi dipahami sebagai upaya untuk mengatur dan mengendalikan perilaku masyarakat agar lebih tertib mengelola berbagai sumber daya dan mendistribusikannya Kepada setiapa anggota masyarakat secara berkeadilan.Perilaku birokrasi di Indonesia berkaitan dengan praktek birokrasi yang dibangun dari proses kesejarahan yang amat panjang, dari warisan kerajaan-kerajaan yang ada sampai pada lamanya masa kolonialisme. Sejarah perjalanan birokrasi di Indonesia tidak pernah terlepas dari pengaruh sistem politik yang berlangsung. Apapun sistem politik yang diterapkan selama kurun waktu sejarah pemerintahan di Indonesia birokrasi tetap memegang peran sentral dalam kehidupan masyarakat. Baik dalam sistem politik yang sentralistik maupun sistem politik yang demokratis sekalipun, seperti yang diterapkan di Negara-negara maju, keberadaan birokrasi sulit dijauhkan dari aktivitas-aktivitas dan kepentingankepentingan politik pemerintah.

Birokrasi merupakan sarana untuk menjalankan tujuan-tujuan yang ingin dicapai. Dimana setiapa pekerjaan atau pejabat dalam birokrasi pemerintahan merupakan pemicu dan penggerak dari sebuah tugas yang bukan merupakan kepentingan pribadi. Maka setiap pejabat pemerintahan tidak mempunyai tanggung jawab publik kecuali pada bidang tugas dantanggung jawab sebagai mesin itu dijalankan sesuai dengan proses dan prosedur yang telah di tetapkan. Maka akuntabilitas pejabat birokrasi pemerintahan telah diwujudkan. Negara berkembang terutama di Indonesia, pelayanan yang diberikan kepada masyarakat belum bisa dikatakan baik karena pelayanan publik yang disediakan oleh pemerintah belum bisa dinikmati oleh seluruh lapisan masyarakat. Hal ini disebabkan oleh beberapa faktor yaitu: kondisi geografis, sumber daya manusia, sumber finansial, dan teknologi informasi.

Terkait dengan bidang penelitian yang dilakukan, maka peneliti mencoba bertitik tolak pada penelitian terdahulu yaitu penelitian Ramading (2017), dengan judul penelitian "pengaruh perilaku birokrasi terhadap pelayanan masyarakat" yang bertujuan untuk mengetahui pengaruh perilaku birokrasi terhadap pelayanan masyarakat dan hasilnya menggambarkan pelayanan masyarakat yang dijalankan kurang baik.Dari 5 indikator yang diterapkan, dapat dijelaskan bahwa:

1. Kepastian, yang mana keinginan atau harapan masyarakat terkait dengan hal yang diinginkan, tapi kenyataan yang terjadi dilapangan, keinginan masyarakat belum bisa terpenuhi, dikarenakan kurangnya perhatian dari aparat pemerintah.

2. Kehandalan yang dibahas di sini masalah ketepatan waktu pelayanan dan kedisiplinan pegawai, serta kemampuan pegawai dalam penyampaian pelayanan yang jelas, namun ketepatan waktu yang digunakan pegawai tidak tepat waktu dan tidak sesuai dengan aturan yang ada.

3. Daya tanggap, yaitu kemauan/keinginan untuk membantu serta melayani masyarakat dalam memberikan jasa secara tepat, kesanggupan aparat desa yang masih kurang mampu melayani masyarakat secara tepat.

4. Empati, kemampuan untuk berbagi perasaan yang dilandasi oleh rasa kepedulian, dimana ketidakmampuan pegawai dalam memahami apa yang diinginkan/dibutuhkan masyarakat seperti, mereka ingin pengurusan yang cepat selesai namun kenyataannnya dilakukan dengan lambat.

5. Bukti fisik, penampilan fasilitas fisik, lingkungan kantor, serta kedisiplinan pegawai dalam memberikan pelayanan, disini juga kedisiplinan pegawai kantor yang menjadi keluhan masyarakat yang ingin dilayani, karena proses pengurusan di kantor berjalan lambat, dan penampilan fasilitas fisik serta lingkungan yang ada disana masih kurang.

Berdasarkan hasil pengamatan awal yang dilakukan peneliti, dengan melakukan wawancara kepada masyarakat pada hari 
Rabu, 19 Desember 2018 pukul 13.20 WITA, pernyataan sebagai berikut:

"pegawai di sana itu, kadang seperti mau kadang juga seperti tidak mau melayani. Seandainya tidak kami butuhkan jasanya, kami tidak ingin rasanya berhadapan dengan orang-orang di sana. Tapi tidak semua seperti itu, ada juga beberapa yang masih peduli dan bersikap baik kepada kami saat proses pelayanan".Adanya keluhan dari masyarakat terhadap proses birokrasi yang diberikan aparat Desa Timoreng Panua, yang mana aparat desa yang ada disana kurang peduli dan kurang tanggap terhadap kebutuhan layanan masyarakat, hal ini terlihat dari berbagai sektor pelayanan yang merupakan kebutuhan dasar dari masyarakat seperti halnya, pengantar kartu keluarga, kartu tanda penduduk, keterangan surat berdomisili, keterangan warisan, perizinan, prosedurpengurusan dan penerbitan sertifikat dan akte tanah, prosedur mengurus surat nikah/cerai, surat kematian, pelayanan PBB, surat keterangan tidak mampu, akta kelahiran. Selain itu, kedisiplinan aparat yang rendah menyebabkan aparat lalai dalam melaksanakan tugas dan tanggung jawabnya sehingga ketepatan waktu saat masyarakat melakukan pelayanan menjadi tertunda dan tidak jelas.

Uraian permasalahan diatas, maka penulis tertarik untuk mengangkat judul penelitian Pengaruh Perilaku Birokrasi Terhadap Pelayanan Publik di Desa Timoreng Panua Kecamatan Panca Rijang Kabupaten Sidenreng Rappang dengan tujuan Untuk mengetahui perilaku birokrasi aparat di Desa Timoreng Panua Kecamatan Panca Rijang Kabupaten Sidenreng Rappang, Untuk mengetahui pelayanan publik di Desa Timoreng Panua Kecamatan Panca Rijang Kabupaten Sidenreng Rappang dan Untuk mengetahuipengaruh perilaku birokrasi terhadap pelayanan publik di Desa Timoreng Panua Kecamatan Panca Rijang Kabupaten Sidenreng Rappang.

\section{Perilaku Birokrasi}

Perilaku merupakan aktualisasi sikap seseorang atau sekelompok orang dalam mewujudkan tindakan aktifitas sebagi hasil interaksi dengan lingkungan. Tindakan dan aktifitas tersebut didasari atas kebutuhan, motivasi dan tujuan, sedangkan lingkungan adalah organisasi dimana individu atau kelompok itu berkarya.Menurut Thoha perilaku organisasi pada hakikatnya mendasarkan pada ilmu perilaku itu sendiri yang dikembangkan dengan pusat perhatiannya pada tingkah laku manusia dalam suatu organisasi. Sementara itu interaksi dengan lingkungan merupakan suatu bagian penting dari proses belajar seseorang. Oleh karenanya kepribadian seseorang sangat dipengaruhi oleh pengalamannya, termasuk interaksinya dengan lingkungannya. (Nawawi, 2015)
Menurut
(Samad,
2016)

mengemukakan bahwa Birokrasi merupakan instrumen penting dalam masyarakat modern yang kehadirannya tidak mungkin terelakkan. Eksistensi birokrasi ini sebagai konsekuensi logis dari tugas utama negara (Pemerintah) untuk menyelenggarakan kesejahteraan masyarakat (social welfare). Untuk itu, negara membangun sistem yang bertujuan untuk melayani kebutuhan rakyatnya yang disebut dengan istilah "Birokrasi".Birokrasi merupakan sistem yang mencoba memahami perilaku-perilaku di dalam organisasi bisa tetap rasional sehingga efektif usaha pencapaian tujuan organisasi tersebut. Arti birokrasi secara teoretik dan konsepsional lebih luas dari pada penggabungan harfiah dari kedua asal kataini. Dalam perkembangnya, arti birokrasi itu bisa berkembang sesuai konteksnya, bahkan ada yang mengartikan bahwa birokrasi itu berdasarkan kenyataannya apa yang dilihat. Artinya ia bisa bermakna positif, negatif atau sesuatu yang netral-netral saja.

Birokrasi berasal dari kata "bureau" yang berarti meja atau kantor: dan kata "cratein" yang berarti pemerintahan. Pada mulanya, istilah ini digunakan untuk menunjuk pada suatu sistematika kegiatan kerja yang diatur atau diperintahkan oleh suatu kantor melalui kegiatan-kegiatan administrasi. Dalam konsep bahasa inggris secara umum, birokrasi disebut dengan "civil service". Selain itu juga sering disebut dengan public sector, public service atau public administration.sedangkan dalam kamus akademik Prancis memasukkan kata tersebut pada tahun 1978 dengan arti kekuasaan, pengaruh dari kepala dan staf biro pemerintahan.

Menurut Albrow (Mustafa, 2014), Pemahaman tentang perilaku birokrasi, tidak dapat terlepas dari pemahaman tentang perilaku organisasi. Hal ini dikarenakan "birokrasi merupakan salah satu bentuk 
organisasi rasional".Menurut Dennis Wrong (Samad, 2016), bahwa birokrasi oleh Weber dipandang sebagai satu manifestasi dari proses rasionalisasi. Wrong mencatat bahwa

a. Birokrasi adalah organisasi yang diangkat sepenuhnya untuk mencapai satu tujuan tertentu dari berbagai aneka tujuan.

b. Birokrasi diorganisasikan secara hierarki dengan jalinan komando yang tegas dari atas ke bawah.

c. Menciptkan pembagian pekerjaan dengan tugas yang spesifik.

d. Adanya peraturan umum dan ketentuan yang menuntut semua sikap dan usaha untuk mencapai tujuan.

e. Karyawan dipilih terutama berdasarkan kompetensi dan keterlatihan.

f. Kerja dalam birokrasi cenderung merupakan pekerjaan seumur hidup.

Konteks perilaku maka keberhasilan birokrasi pemrintah diukur dari kemampuannya melaksanakan visi sebagai mana yang telah ditentukan. Birokrasi dituntut para aparaturnya menghayati dan mencerminkan seperangkat nilai-nili dalam sikap perilakunya sehari-hari, senantiasa berusaha mengembangkan diri sebagai panutan/teladan dengan memiliki moralitas yang tinggi, menghindarkan diri dari perbuatan tercela.Siagian (Oktamiati, 2017) mengklasifikasikan perilaku birokrasi yang harus ditampilkan dalam memberikan pelayanan kepada masyarakat, antara lain :
a. Kesopanan
b. Keadilan
c. Kepedulian
d. Kedisiplinan
e. Kepekaan
f. Tanggung jawab

\section{Pelayanan Publik}

Pelayanan merupakan suatu perbuatan, suatu kinerja atau suatu usaha, jadi menunjukkan secara inheren pentingnya penerima jasa pelayanan terlibat secara aktif di dalam produksi atau penyampaian proses pelayanan itu sendiri (Warella, 2004). Menurut (Robert, 2016) yang dimaksud dengan pelayanan publik adalah: "Segala bentuk kegiatan pelayanan umum yang dilaksanakan oleh instansi pemerintah pusat, di daerah dan lingkungan badan usaha milik negara atau daerah dalam barang atau jasa baik dalam rangka upaya pemenuhan kebutuhan masyarakat maupun dalam rangka pelaksanaan ketertiban-ketertiban".
Pelayanan publik adalah kegiatan atau rangkaian kegiatan dalam rangka pemenuhan kebutuhan pelayanan sesuai dengan peraturan perundang-undangan bagi setiap warga negara dan penduduk atas barang, jasa, dan/atau pelayanan administratif yang disediakan oleh pelayanan penyelenggaraan publik.Pelayanan publik yang diselenggarakan oleh birokrasi publik adalah merupakan salah satu perwujudan dari fungsi aparatur negara sebagai abdi masyarakat disamping sebagaiaabdi negara, Saefullah (Samad, 2016), Penyelenggaraa publik dimaksudkan untuk mensejahterakan masyarakat dari suatu negara kesejahteraan (welfare state).Kualitas pelayanan publik (Sinambela, \&amp; Poltak, 2014), secara teoritis tujuan pelayanan publik pada dasar adalah memuaskan masyarakat. Untuk mencapai kepuasan itu dituntut kualitas pelayanan prima yang tercermin dari:

a. Kehandalan. Kehandalan adalah suatu penerapan perancangan pada komponen sehingga komponen dapat melaksanakan fungsinya dengan baik, tanpa kegagalan, sesuai rancangan atau proses yang dibuat. Serta mampu untuk memberikan jasa yang dijanjikan secara terpercaya, akurat dan memuaskan.

b. Daya Tanggap. Menurut(Lupiyoadi, 2001) daya tanggap adalah "suatu kemauan untuk membantu dan memberikan pelayanan yang cepat (responsif) dan tepat kepada pelanggan, dengan penyampaian informasi yang jelas.

c. Kepastian. Kepastian juga merupakan pengetahuan, kesopansantunan, dan kemampuan para pegawai perusahaan untuk menumbuhkan rasa percaya para pelanggan kepada perusahaan.

d. Empati. Menurut Carkhuff, Empati sebagai kemampuan untuk mengenal, mengerti dan merasakan perasaan orang lain dengan ungkapan verbal dan perilaku, dan mengkomunikasikan pemahaman tersebut kepada orang lain.

e. Bukti Fisik. Definisi bukti langsung dalam (Lupiyoadi, 2001) yaitu "kemampuan suatu perusahaan dalam menunjukkan eksistensi kepada pihak eksternal. Penampilan dan kemampuan sarana dan prasarana fisik perusahaan dan keadaan lingkungan sekitarnya adalah bukti nyata dari pelayanan yang diberikan oleh pemberi jasa, yang meliputi fasilitas fisik (gedung, gudang, dan lain sebagainya), 
perlengkapan dan peralatan yang dipergunakan (teknologi), serta penampilan pegawainya".

\section{B. METODE PENELITIAN}

Penelitian inidilaksanakan di Desa Timoreng Panua Kecamatan Pancarijang Kabupaten Sidenreng Rappang dan dilaksanakan selama bulan Maret-Mei 2019. Penelitian ini menggunakan jenis penelitian dekriptif kuantitatif yaitu metode yang lebih menenkankan pada aspek pengukuran secara objektif terhadap fenomena sosial. Untuk dapat melakukan pengukuran, setiap fenomena dijabarkan kedalam beberapa komponen masalah, variabel dan indikatornya.Dalam penelitian ini yang menjadi populasi adalah masyarakat yang melakukan pelayanan di Kantor Desa Timoreng Panua selama bulan Desember 2018-Januari 2019 sebanyak 57 orang.

Teknik penarikan sampel dalam penelitian ini menggunakan Sampling jenuh, yang mana teknik pengumpulan sampel ini bila semua anggota populasi digunakan sebagai sampel.Teknik pengumpulan data yang digunakan dalam penelitian ini adalah Observasi, Dokumentasi, Kuisioner, Studi kepustakaan. Teknik analisis data dalam penelitian kuantitatif menggunakan statistik, data yang terkumpul akan dianalisis regresi sederhana dengan bantuan program SPSS (Statistik Product and Service Solution) for windows.

\section{HASIL DAN PEMBAHASAN}

\section{Perilaku Birokrasi}

Rekapitulasi tanggapan responden mengenai indikator perilaku birokrasi

\begin{tabular}{|c|c|c|}
\hline No & $\begin{array}{c}\text { Tanggapan } \\
\text { Responden }\end{array}$ & Persentase \% \\
\hline 1 & Kesopanan & $64,2 \%$ \\
\hline 2 & Keadilan & $60,2 \%$ \\
\hline 3 & Kepedulian & $56 \%$ \\
\hline 4 & Kedisiplinan & $60,2 \%$ \\
\hline 5 & Kepekaan & $62,8 \%$ \\
\hline 6 & Tanggung Jawab & $68 \%$ \\
\hline \multicolumn{2}{|c|}{ Rata-rata persentase } & $61,9 \%$ \\
\hline \multicolumn{2}{|c|}{ Sumber Hasil Olahan Data Kuesioner 2019}
\end{tabular}

Berdasarkan dari tabel valiabel Perilaku Birokrasi diatas terdapat enam indikator yang digunakan dalam perilaku birokrasi yang digunakan oleh peneliti di kantor Desa Timoreng Panua Kabupaten Sidenreng Rappang.
Dari indikator pertama yaitu kesopanan, dari hasil rata - rata persentase olahan data kuisioner didapatkan $64,2 \%$ termasuk dalam kategori baik. Dilihat dari hasil rata-rata olahan data tersebut, masyarakat menganggap bahwa aparat desa Timoreng Panua memiliki sikap yang sopan terhadap masyarakat yang ingin melakukan pelayanan, tetapi dari hasil observasi peneliti menganggap bahwa aparat desa Timoreng Panua masih kurang sopan dalam menghadapi masyarakat, bisa dilihat dari segi penampilan dimana terkadang ada aparat desa yang sudah tidak menggunakan pakaian kantor serta hanya memakai sandal tetapi masih dalam waktu jam kantor.

Indikator kedua yakni keadilan dari hasil rata - rata persentase didapatkan $60,2 \%$ termasuk dalam kategori kurang baik. Dapat diketahui bahwa aparat desa Timoreng panua masih kurang peduli dengan apa yang dibutuhkan masyarakat ketik ke kantor desa dapat dilihat dari hasil olahan data yanng masih kurang baik. Tapi dari hasil observasi peneliti melihat bahwa aparat desa disana tidak membeda-bedakan setiap masyarakat yang datang ke kantor desa untuk dilayani hanya saja terkadang bisa masih lambat dalam proses penyelesaian pengurusan.

Indikator ketiga yakni kepedulian dari hasil rata - rata persentase olahan data kuisioner didapatkan $56 \%$ termasuk dalam kategori kurang baik. Dilihat dari hasil rataratanya masih ada masyarakat yang menganggap bahwa aparat desa yang ada di kantor desa Timoreng Panua masih dalam kategori rendah. Hal ini dapat disimpulkan sesuai dengan hasil observasi penelitian dimana masih ada sebagian dari aparat desa yang memiliki sikap cuek terhadap apa yang dibutuhkan masyarakat, terkada mereka saling suruh nyuruh sehingga pelayanan berjalan lambat.

Indikator keempat yakni kedisiplinan dari hasil rata - rata persentase olahan data kuisioner didapatkan $60,2 \%$ termasuk dalam kategori kurang baik. Dimana setiap masyarakat tentunya sangat menginginkan pelayanan yang mudah, cepat, dan tepat, salah satu faktor yang mendukung keberhasilan aparat dalam mewujudkan kehendak masyarakat tersebut adalah dimilikinya sikap disiplin dari aparat desanya, maka dari hasil olahan data dapat disimpulkan bahwa Kantor desa Timoreng Panua dalam menjalankan tugasnya untuk 
memberikan pelayanan kepada masyarakat yang masih belum maksimal dalam masalah kedisiplinan waktunyanya, ini juga dapat dilihat dari hasil observasi peneliti di Kantor desa Timoreng Panua yang masih kurang baik di karenakan terkadang setelah jam istirahat berakhir 2 sampai 3 orang tidak kembali lagi ke kantor untuk melaksanakan kewajibannya.

Indikator kelima yakni kepekaan dari hasil rata - rata persentase olahan data kuisioner didapatkan $62,8 \%$ termasuk dalam kategori baik. Bisa disimpulkan bahwa masyarakat yang ada di sana menganggap aparat desa Timoreng Panua sudah merespon masyarakat dengan cukup baik dalam memberikan pemahaman kepada masyarakat jika masih ada yang belum kurang mengerti dan juga menyelesaikan masalah yang juga tidak dapat diselesaikan oleh masyarakat itu sendiri. Montessori mengatakan "selama priode tertentu akan memiliki kepekaan terhadap unsur tertentu yng memaksa dia untuk memfokuskan erhatannya pada aspek tertentu di lingkungnnya".

Indikator yang terakhir indikator keenam yakni tanggung jawab dari hasil rata - rata persentase olahan data kuisioner didapatkan $61,9 \%$ termasuk dalam kategori baik. Dapat dijabarkan bahwa aparat desa Timoreng Panua sudah berusaha memberikan pelayanan yang baik kepada masyarakatnya, dan bertanggung jawab dalam memberikan pelayanan kepada masyarakat. Namun masih memiliki kelemahan dalam melaksanakan tugas yaang terkadang masih lambat dan berbelitbelit, tetapi aparat desa disana sudah cukup baik dalam melaksanakan tanggung jawabnya terkait tugas yang diberikaan.

\section{Pelayanan Publik}

Rekapitulasi tanggapan responden

mengenai indikator pelayanan publik

\begin{tabular}{|c|c|c|}
\hline No & $\begin{array}{c}\text { Tanggapan } \\
\text { Responden }\end{array}$ & Persentase \% \\
\hline 1 & Kehandalan & $56 \%$ \\
\hline 2 & Daya Tanggap & $70 \%$ \\
\hline 3 & Kepastian & $63,2 \%$ \\
\hline 4 & Empatik & $73,6 \%$ \\
\hline 5 & Bukti Fisik & $61,4 \%$ \\
\hline \multicolumn{2}{|c|}{ Rata-rata Persentase } & 64,84 \\
\hline
\end{tabular}

Sumber Hasil Olahan Data Kuesioner 2019

Hasil tabel variabel Pelayanan Publik diatas terdapat lima indikator yang digunakan dalam pelayanan publik yang digunakan oleh peneliti di kantor Desa Timoreng Panua Kabupaten Sidenreng Rappang, Dari indikator pertama dari hasil rata - rata persentase didapatkan $56 \%$ dalam kategori kurang baik. masyrakat masih menganggap bahwa Kemampuan pegawai kantor desa yang ada di sana untuk memberikan pelayanan belum sesuai dengan yang dijanjikan secara akurat dan terpercaya. Ini dapat dilihat dari hasil olahan data kusioner masyarakat. Dimana kemampuan pegawai untuk memberikan pelayanan belum sesuai dengan apa yang telah dijanjikan kepada masyarakat secara akurat dan terpercaya Kinerja harus sesuai dengan harapan masyarakat yang berarti ketepatan waktu, pelayanan yang sama untuk semua pelanggan tanpa kesalahan.

Indikator kedua yakni daya tanggap dari hasil rata - rata persentase didapatkan $70 \%$ termasuk dalam kategori baik. Dilihat dari hasil rata-rata yang didapatkan sebagian masyarakat masih menganggap bahwa daya tanggap yang dimiliki oleh aparat desa sudah baik bagi masyarakat. Berdasarkan pengamatan peneliti melihat bahwa kegiatan pelayanan yang dilakukan oleh aparat masih terkesan lambat karena masih ada sebagian aparat desa yang terkesan santai dalam menanggapi probleman yang dihadapi oleh masyarakatnya, serta kurang profesional dalam bekerja sehingga membut proses pelayanan atau penyelesaian pengurusan menjadi lambat dan tidak tepat waktu.

Indikator ketiga yakni kepastian dari hasil rata - rata persentase didapatkan $63,2 \%$ dalam kategori baik. Dengan melihat hasil rata-rata diatas masyarakat diyakini bahwa pegawai tersebut mampu memberikan pelayanan yang handal, mandiri dan profesional yang berdampak pada kepuasan pelayanan yang diterimanya. Terlihat dari hasil pengamatan awal peneliti pelayanan yang diberikan aparat desa kepada masyarakat yang ingin dilayani terkadang berlangsung lebih dari satu hari jadi masyarakat terkadang kembali lagi dihari berikutnya untuk mengecek apakah urusan surat menyuratnya telah selesai

Indikator keempat yakni empatik dari hasil rata - rata persentase didapatkan $73,6 \%$ dalam kategori baik.. Dari hasil data diatas menurut anggapan masyarakat aparat desa yang ada di desa Timoreng Panua Memberikan perhatian yang baik dan bersifat 
individual atau pribadi terhadap yang diberikan kepada para masyarakatnya dengan berupaya memahami keinginan masyarakat. Dimana suatu kantor diharapkan memiliki pengertian dan pengetahuan tentang masyarakat, memahami kebutuhan masyarakat secara spesifik, serta memiliki waktu pengoprasian yang nyaman bagi pelanggan.

Indikator yang terakhir indikator kelima yakni bukti fisik dari hasil rata - rata persentase didapatkan $61,4 \%$ dalam kategori baik. masyarakat yang ingin mengurus di kantor desa menganggap bahwa penampilan prasarana fisik maupun penampilan pegawai sudah baik ini dapat dilihat dari hasil olahan data kuisioner. Namun apa yang diamati peneliti Penampilan dan kempampuan sarana dan prasarana fisik kantor desa masih kurang dapat diandalakan begitu juga keadaan lingkungan sekitarnya seperti hal ini meliputi fasilitas fisik tidak berfungsinya wc kantor, dan lingkungan kantor yang kurang bersih serta penampilan pegawainya.

\section{Model Summary Pengaruh X terhadap Y} Model Summary

\begin{tabular}{|c|c|c|c|c|}
\hline Model & $\mathrm{R}$ & $\begin{array}{c}\mathrm{R} \\
\text { Square }\end{array}$ & $\begin{array}{c}\text { Adjusted R } \\
\text { Square }\end{array}$ & $\begin{array}{c}\text { Std. Error of } \\
\text { the Estimate }\end{array}$ \\
\hline 1 & $\begin{array}{c}.490 \\
\mathrm{a}\end{array}$ & .240 & .226 & 2.498 \\
\hline
\end{tabular}

a. Predictors: (Constant), $x$

\section{Sumber Hasil olahan data SPSS}

1) $r$ adalah 0,490

2) $r$ Square : $0,240 \times 100 \%=24 \%($ pengaruh $X$ terhadap $Y$ )sisanya 100\% $0,240 \%=76 \%$ ( sisanya dipengaruhi oleh faktor yang lain ) koefisien determinasi ( $r^{2}$ ) digunakan untuk mengetahui pengaruh $X$ terhadap $Y$ dalam menerangkan variasi variabel dependen. Berdasarkan tabel model Summary koefisien determinasi berganda ( $r 2$ ) atau $r$ square $=0,24$ berarti secara bersama-sama $24 \%$ perubahan variabel pelayanan publik $(Y)$ dapat dijelaskan oleh variabel perilaku birokrasi ( $X$ ), atau dengan kata lain pengaruh variabel bebas terhadap variabel terikat sebesar $24 \%$ sedangkan sisanya yaitu $76 \%$ dipengaruhi oleh variabel lain yaang tidak masuk dalam kerangka konsep penelitian.

\section{KESIMPULAN}

Berdasarkan hasil pembahasan di atas, maka dapat disimpulkan sebagai berikut:

1. Perilaku Birokrasi di desa Timoreng Panua Kabupaten Sidenreng Rappang dengan rata-rata $61,9 \%$, ini dapat dilihat dari hasil olah angket setiap indikator pertanyaan, masuk dalam kategori "baik".

2. Pelayanan publik di desa Timoreng Panua Kabupaten Sidenreng Rappang dengan rata-rata $64,84 \%$, ini dapat dilihat dari hasil olah angket setiap indikator pertanyaan, masuk dalam kategori "baik".

3. Pengaruh perilaku birokrasi terhadap pelayanan publik di kantor desa Timoreng Panua Kabupaten Sidenreng Rappang, hanya sebesar $24,0 \%$ dan termasuk dalam kategori "kurang baik". Hal ini menunjukkan bahwa untuk memperbaiki pelayanan public, tidak hanya perbaikan perilaku tapi dibutuhkan factor-faktor lain yang justru tidak diteliti

\section{E. REFERENSI}

Abidin, Zainal. 2010. Analisis Pengaruh Kehandalan Dan Etos Kerja Terhadap Pelayanan Publik Pegawai Kantor Pelayanan Pajak Pratama Medan Kota, Medan: USU

Ahmad, Jamaluddin. 2015. Metode Administrasi Publik Teori Dan Aplikasi. Yogyakarta: Gava Media.

Aprilia. 2014. Pembangunan Berbasis Masyarakat. Bandung: Alfbeta.

A, Parasuraman. 2001. The Behaviorial Consequenses Of Service Quality, Jurnal Of Marketing. Vol 60.

Dwiyanto, A. 2006. Mewujudkan Good Geovernance. Yogyakarta: UGM Press..

Hayat. 2016. Peneguhan Reformasi Birokrasi melalui Penilaian Kinerja Pelayanan Publik. IImu Sosial dan IImu Politik.

Kalsen, Hans. 2006. Teori Utama Tentang Hukum dan Negara, PT. Raja Grafindo Persada Bandung.

Kotler, Philip. 1997. Manajemen Pemesaran, Jakarta: Prehllindo. 
Lupiyoadi, Rambat. 2001. Manajemen Pemasaran Jasa, Teori dan Praktek. Edisi Pertama, Jakarta: Salemba Empat.

Magnis, Franz. 1988. Etika Politik Prinsip Moral Dasar Kenegaraan Modern, Jakarta: Prehllindo.

Mustafa, Delly. 2014. Birokrasi Pemerintahan.Bandung. Alfabeta.

Mulyadi dan Setiawan. 2001. Efektifitas Pelayanan Publik. Pratama. Surabaya

Nawawi, Z. 2015. Manajemen Pemerintahan. Jakarta: RajaGrafindo.

Nasution. 2004. Reformasi Pelayanan Publik. Bumi Aksara. Jakarta.

Nurmandim. 2005. Perilaku Birokrasi Publik di Indonesia. Sebuah Kajian Teoritis, $7,143-157$

Oktamiati. 2017. Persepsi Masyarakat terhadap Perilaku Birokrasi di Kelurahan Kadidi Kecamatan Panca Rijang Kabupaten Sidenreng Rappang. STISIP M Rappang.

Pananrangi, A.R. \& Marlinah. 2017. Etika Birokrasi. Makassar: Sah Media.

Poewadarminta W.J.S. 1986. Kamus Besar Umum Indonesia, Jakarta: Balai Pustaka

Ratminto \& Septi, W. A. 2016. Manajemen Pelayanan. Yogyakarta: Pustaka Pelajar.

Razak, M. R. R. (2020, March 9). Pemanfaatan Teknologi Informasi dalam Optimalisasi Pelayanan Publik dan Potensi Desa. https://doi.org/10.31219/osf.io/nfhu9

Razak, M.R.R;Harfiah, S. (Universitas M. S. R. (2018). Partisipasi Masyarakat di Daerah Pegunungan terhadap Perwujudan Good Governance. Akmen Jurnal IImiah, 15(3), 476-486.

Robert. 2016. mewujudkan good governance melalui pelayanan publik. ilmu politik dan komunikas, VI, 8.
Said, S. \& Haedar, A. 2018. Reformasi Pelayanan Publik di Negara Berkembang. Makassar: Sah Media.

Samad, Zainuddin. 2016. Birokrasi dalam Pelayanan publik. Yogyakarta. Penerbit Ombak.

Sellang, Kamaruddin. 2016. Administrasi dan Pelayanan Publik. Yogyakarta: Penerbit Ombak.

Saragih, 2010. Pengaruh Remunerasi terhadap Kualitas Pelayanan Publik. IImu Administrasi dan Organisasi, 17, 43-51.

Setiawan, I. 2014. Rekonstruksi Birokrasi Pemerintahan Daerah. Yogyakarta: Widya Mandala.

Sinambela, \& Poltak, L. 2014. Reformasi Pelayanan Publik. Jakarta: PT Bumi Aksara.

Sugiyono. 2015. Metode Penelitian Kombinasi. Bandung: Alfabeta.

Tjiptono, Fandy. 1996. Manajemen Jasa, Penerbit Andi. Yogyakarta.

Tjiptono, Fandy. 1997. Strategi Pemasaran, Edisi 1. Penerbit Andi. Yogyakarta..

Thoha, Miftah. 2008. Perilaku Organisasi : Konsep Dasar dan Aplikasinya, Jakarta: Raja Grafindo Persada.

Warella. 2004. kualitas pelayanan publik. dialogue, 1, 113.

Widodo, Joko. 2001. Good Governance: Telaah dari Dimensi: Akuntabilitas dan Kontrol Birokrasi pada Era Desentralisasi dan Otonomi Daerah, Insan Cedekia. Surabaya.

Yusriadi, \& Misnawati. 2017. Reformasi Birokrasi Dalam Pelayanan Publik. IImiah IImu Administrasi Publik, 104.

Zainuddin. 2017. Teori-Teori Mutakhir Dalam Perspektif Ilmu Administrasi Publik. Makassar: Phinatama Media

\section{Dokumen :}

Al-Qur'an Surah An-Nisa. 
Undang-Undang Nomor 25 Tahun 2009 tentang Pelayanan Publik.

Undang-Undang Nomor 23 Tahun 2014 tentang Pemerintahan Daerah.

Undang-Undang Nomor 63 Tahun 2003 tentang Keputusan Menteri

Pemberdayaan Aparatur Negara. 